\title{
KONSEPTUALISASI SISTEM PENDIDIKAN ISLAM: Belajar melalui Masa Keemasannya
}

\author{
Muh. Akib D. \\ Sekolah Tiggi Agama Islam DDI Ujung Lare Kota Parepare \\ Jl. Abu Bakar Lambogo No. 53 Parepare 91131 Sulawesi Selatan \\ Email: dr.akib1965@gmail.com
}

\begin{abstract}
Abstrak:
Islam memiliki masa keemasan dalam sejarah selama abad pertengahan. Kemajuan dalam berbagai aspek kehidupan sangat jelas khususnya dalam bidang sains dan teknologi dari berbagai disiplin dengan tokohnya yang sangat terkenal di masa itu seperti Al-Kindi, Ibn Sina, Al-Gazali, dan yang lainnnya. Pada masa itu orang muslim tidak memandang agama dan pengetahuan sekular sebagai dikotomi. Semangat kebijaksanaan yang begitu tinggi yang dimulai dengan membentuk banyak lembaga dan berusaha keras untuk menerjemahkan naskah-naskah filsafat Yunani kuno. Selanjutnya kekuatan besar yang ditunjukkan oleh semua pihak baik pembuat aturan maupun masyarakat telah menjadi deklarasi umum, untuk keagungan Islam.
\end{abstract}

\begin{abstract}
:
Islam had its golden age in the history during the middle age. Progress in many aspects of life was of the clear signs especially that of science and knowledge of various disciplines with the very well known scholars of their time like Al-Kindi, Ibnu Sina, Al-Ghazali, and others. Those days the Muslims did not see the religious and secular knowledge as a dichotomy. The zeal for wisdom was so high that they started many institutes and made such huge efforts to translate the scripts of the ancient Greek's philosophy. In addition, great vehemence shown by all (the ruler as well as the people) had really become a common oath, which was for the universal glory of Islam.
\end{abstract}

\section{Kata Kunci: \\ Pendidikan, Tekad Kerja, dan Islam Based}

SUMBER utama dan pertama akan penyusunan konsep pendidikan dalam tulisan ini merupakan hasil riset Horward R. Turner yang mendapat tugas untuk menggelar The Heritage of Islam, suatu pameran seni dan sains sejarah Islam dengan disponsori oleh National Committee to Honor the White Ceintinnial of Islam pada 5 museum utama di Amerika Serikat antara tahun 1982 hingga tahun 1983. Turner berperan sebagai kurator tenaga ilmiah. Ia dibantu oleh beberapa sejarawan sains terkemuka antara lain: Prof. A. I. Sabra, ahli sejarah sains Arab dari Universitas Harvard; Dr. Sani K. Haneruch, kurator emiritus dari Departemen Sejarah Sains di museum Sejarah Nasional Amerika Serikat; Prof. David A King, mantan Lektor Kepala Bahasa Arab dan Sejarah Sains pada Universitas New York; dan beberapa Guru Besar Sejarah Sains Islam dari Universitas Harvard lainnya.

Turner sendiri adalah seorang penulis TV, film dokumenter, dan pendidikan. Ia mengawali laporannya dengan mengadakan tinjauan historis penyebaran peradaban Islam dari semenanjung Arabia ke Timur sampai India, dan ke Barat melintas Afrika 
Utara hingga Spanyol. Ia menggambarkan, selama berabad-abad bagaimana Islam membangun imperium kekuasaan. ${ }^{1}$

Sumber utama kedua adalah teori membangun institusi perusahaan raksasa di Amerika Serikat, Good to Great oleh Jim Collins, 2001, dan Built to Last oleh James C. Collins dan Jerry I. Porras, 2000. Mencermati uraian-uraian dari kedua buku tersebut, semestinya buku Buil to Last lahir sesudah buku Good to Great, namun begitulah kenyataannya, seringkali penulisan ilmiah datang dengan kebalikan waktu. ${ }^{2}$ Kedua sumber tersebut sengaja dijadikan sumber rujukan dengan tujuan untuk menunjukkan bahwa kebenaran ilmiah yang Islam based dapat diakui dan dapat diterapkan oleh ilmuan dari agama apapun dan di negara manapun.

\section{Belajar dari Sumber Pertama}

Warisan abad keemasan Islam bagaikan harta karun kekayaan peradaban intelektual yang tidak ternilai harganya, menyebar hampir ke seluruh dunia melampaui kekayaan imperium Romawi, 7 abad sebelumnya. Dalam kesempatan yang amat terbatas ini, hanya akan dikutip beberapa butir nilai intelektual peradaban emas itu yang relevan dengan kebutuhan saat ini, antara lain:

Pertama: Semangat mencari ilmu yang luar biasa dari orang-orang Islam. Hal ini karena dipicu oleh ajaran Islam, bahwa mencari ilmu, mengembangkan dan kemudian mengamalkannya untuk membangun kehidupan adalah wajib hukumnya. Semangat pencarian ilmu tersebut menjadi kunci penjelajahan intelektual Islam pada puncak kemajuannya pada abad ke-9, 10, dan 11. Masa ini muncul bersamaan dengan datangnya peradaban baru dan ajaran Al-Quran tentang dunia.

Kedua: Semangat pencarian ilmu tersebut menemukan momentumnya dalam inperium Islam khilafah Abbasiyah, Al-Mansūr, Hārūn al-Rasyīd, dan Al-Ma'mūn yang sangat kuat mendorongan dan mengucurkan dana serta fasilitas besar dari istana untuk mempercepat perkembangan peradaban baru yang knowledge based.

Ketiga: Peradaban baru tersebut berkembang dengan cepat karena menggunakan pendekatan logos dan mitos, yaitu pendekatan rasional berdasarkan sains yang adil dan manusiawi terhadap aturan-aturan masyarakat di daerah-daerah yang ditaklukkan, tanpa mengabaikan keterkaitannya dengan kekuatan-kekuatan mistis di luar kemampuan sains, yaitu dengan pendekatan mitos dimaksud. Kedua pendekatan tersebut benar-benar merupakan pendekatan yang bertolak dari wahyu Al-Quran. Sejak awal, cendekiawan muslim sangat tertarik mempelajari ilmu-ilmu yang dapat diterapkan untuk membangun kehidupan di dunia nyata ini, bagaikan membangun kehidupan yang merupakan bayang-bayang kehidupan surgawi.

Keempat: Dalam abad keemasan tersebut muncul 5 tokoh pendekar ilmuan yang menjadi penggerak dan penggolak intelektual Islam sekaligus merupakan founding fathers yang meletakkan dasar-dasar pembangunan kehidupan modern di Eropa. Mereka adalah: (1) Al-Kindi dari Baghdad pada abad ke-9, yang mendapat gelar palymath yaitu orang yang menguasai beberapa cabang ilmu sekaligus; fisika, matematika, optik, musik, kosmologi, dan filsafat. (2) Abu Nashr al-Farābī, dari Turki, pada abad ke-10. Ia dikenal sebagai "guru kedua" sesudah Aristoteles, dialah yang menyelaraskan filsafat helenis dengan wahyu. (3) Ibnu Sīnā, sang genius dalam bidang ke- 
dokteran, pada abad ke-11, di Barat terkenal dengan sebutan Avicenna. Ajaran Ibnu Sīnālah yang mempengaruhi filsafat skolastik yang mendominasi filsafat teologi Kristen abad pertengahan. (4) Al-Ghazālī, ahli hukum Islam abad ke-11, karyanya merupakan simbol kebangkitan ilmu keagamaan dan membongkar ketidak konsistenan para filosof. Melalui ajarannya pula pendidikan Islam menjadi lebih inklusif, harmonis, dan lebih mampu menyatukan unsur-unsur filsafat, teologi, dan mistis. Karyakaryanya juga berpengaruh dengan kuat terhadap filsafat Kristen dan Yahudi. (5) Ibnu Rusyd, di Barat terkenal dengan Averroes, pada abad ke-11 dan 12. Ajarannya merupakan puncak yang paling bercahaya di Spanyol. Ia berkeyakinan bahwa keberadaan Tuhan dapat dijelaskan dengan landasan rasional semata. Ia merupakan bapak berpikir bebas, sehingga ia dianggap kafir. Namun tuduhan ini tidak menyurutkan namanya sebagai cendekiawan muslim yang cemerlang dan meninggalkan pengaruh baik pada pemikiran Kristen dan Yahudi. Bagi Ibnu Rusyd dan Al-Kindi, elit terpelajar dapat dibimbing dengan penalaran, sementara massa yang kurang beruntung dapat dibimbing dengan keyakinan.

Kelima pendekatan inilah yang menggunakan pendekatan logos dan mitos dimaksud di atas, yang mengintegrasikan logos dan mitos dalam two in one.

Kelima: Islam pada zaman abad keemasan hebat karena menguasai dan menggunakan sains dalam mengembangkan peradaban baru. Sejak abad pertama, dunia Islam sudah mendirikan rumah kebijakan (bait al-hikmah), pusat-pusat studi, pusat penterjemahan buku-buku filsafat Yunani, perpustakaan, yang tersebar di Timur dan Barat. Abad ke-9 di bawah masa Fatimiyah, seperti Al-Azhar yang merupakan universitas tertua di dunia dan akademi sains yang didirikan abad ke-10 di Cordova.

Semangat mempelajari filsafat Yunani Kuno, filsafat alam, terus meggebu. Penerjemahan selama 200 tahun oleh kaum muslimin menghasilkan karya-karya utama Plato, Aristoteles, Euclid, Archimedes, Hipocrates, Galens, Ptolomeus, dan masih banyak lagi tersedia bagi sarjana-sarjana muslim dari Persia sampai Spanyol. Ajaranajaran itu tidak hanya diterima sebagai ajaran "suci" yang diawetkan, dijaga keasliannya, dihafal, tetapi juga dikritisi, diluruskan, dikembangkan dan diaplikasikan dalam bimbingan wahyu.

Keenam: Penyebaran perolehan sains dari dan ke berbagai penjuru dunia tidak monoton tetapi melalui banyak alternatif sesuai dengan etika penyebaran ilmu di zaman sains modern. Silsilah sains Islam (transmisi sains dari zaman lampau hingga abad pertengahan), ${ }^{3}$ sebagaimana dapat dilihat pada diagram berikut ini:

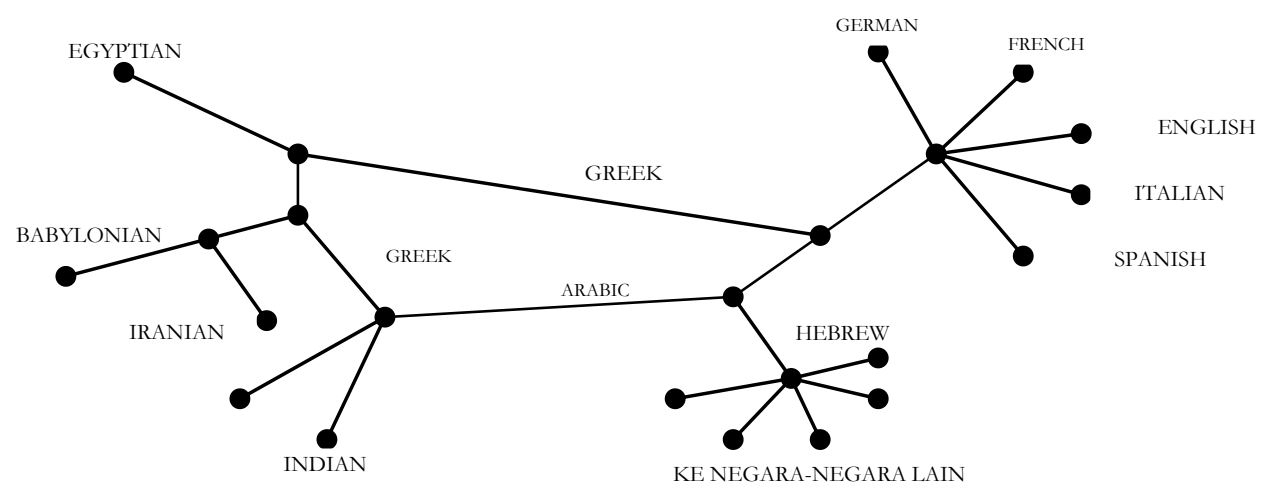


Ketujuh: Kearifan dalam memberlakukan daerah yang ditaklukan: (1) Tidak ada kewajiban pindah agama, yang ada adalah kewajiban membayar pajak, juga tidak ada kewajiban menjalankan tugas militerisasi bagi Kristen dan Yahudi. Sementara bagi penyembah berhala menghadapi resiko yang lebih besar dan bahkan resiko kematian apabila menolak kewajiban bayar pajak dan meluruskan agama, namun aturan ini kurang keras diterapkan bagi daerah-daerah yang sulit dijangkau. (2) Menyadari Islam sebagai "agama bangsa" dari 3 agama langit, muslim menghargai ajaran-ajaran agama Kristen dan Yahudi, mereka bersama-sama kaum Kristen dan Yahudi membentuk masyarakat multietnik dan multinasional yang pertama di dunia, dalam zaman modern ini terkenal sebagai masyarakat multikultural.

Kedelapan: Seiring dengan "rumah kebijakan" di atas, Masjid pada zaman abad keemasan Islam benar-benar menjadi pusat kebudayaan dan berfungsi sebagai pelindung sains eksak dalam proses islamisasi yang merubah sains kuno menjadi sains modern yang berbasis Islam.

Kesembilan: Memasuki abad ke-13 dan berlanjut hingga abad ke-14, keberdayaan Islam mulai menurun dan terus stagnan di akhir abad ke-14. Hal ini disebabkan banyak faktor, di antaranya adalah: (1) Ketika Islam mulai maju, Eropa justru dalam abad kegelapan. Kemudian mereka belajar dari Islam, terus menuju ke pencerahan, dan akhirnya menemukan masa revolusi science and technology sejak awal abad ke-15, dan terus meningkat di akhir abad ke-18 dan seterusnya. Dengan science dan technology Barat membangun ekonomi dan berhasil mendongkrak pendapatan perkapita masyarakatnya yang seterusnya meninggalkan Islam. Sejak Barat menemukan masa renaisans, para ulama dan cendekiawan muslim mulai iri hati, mulai kaku dalam menafsirkan hukum-hukum Islam, dan membatasi pengajaran agama yang diperbolehkan dipelajari oleh sarjana-sarjana agama. (2) Seiring dengan itu, pencarian ilmiah, baik di bidang sains maupun filsafat mendapat serangan yang hebat dari kelompok ortodoks, dengan tuduhan pendangkalan agama. (3) Islam kemudian "mengisolasikan diri", (4) Kecuali itu, dengan semakin banyaknya daerah-daerah baru yang ditaklukkan, bertambah banyak pula penguasa-penguasa baru, dengan tidak diimbangi oleh sistem kontrol yang baik, muncul pula berbagai ragam kebutuhan, keinginan, dan sebagainya yang membawa akibat munculnya kepentingan pribadi, yang semakin jauh dari core values sebagaimana tersebut dalam Al-Quran.

Berikut adalah Flow Chart, hasil studi Ary Muchtar Pedji mengenai abad keemasan Islam. (AMP, 2005):

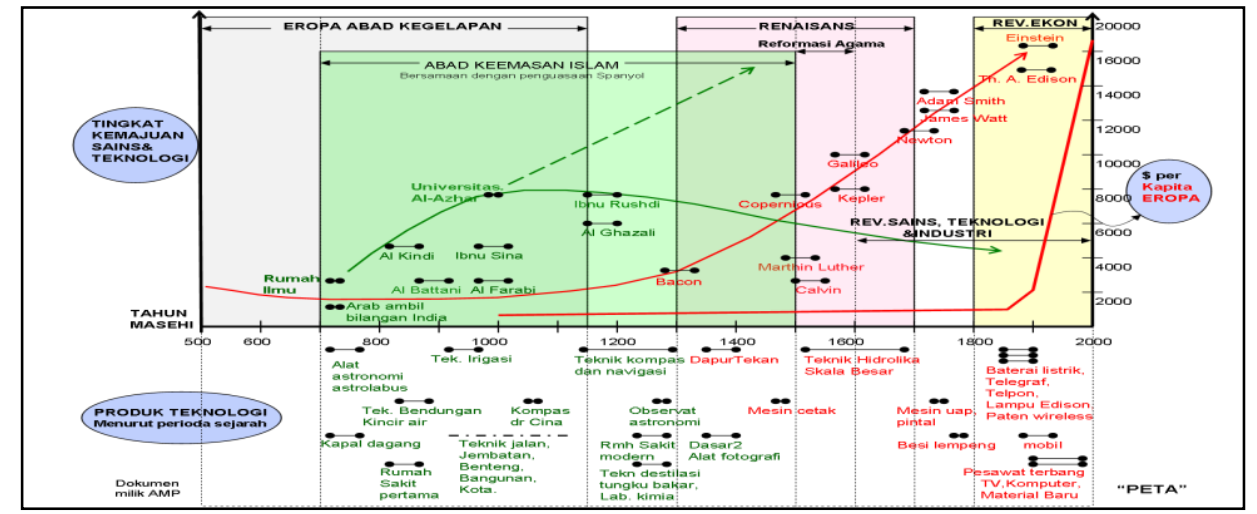




\section{Belajar dari Sumber Kedua}

Konsep membangun pendidikan yang ingin disampaikan berikut adalah "refleksi" dari pelajaran sumber pertama tersebut di atas. Umat Islam Indonesia agak kurang beruntung karena zaman keemasan Islam tidak sempat mampir ke Indonesia, Islam mulai masuk ke Indonesia diperkirakan pada awal abad ke-16 atau akhir abad ke-15. Akhir abad ke-14 merupakan "titik mandeg" zaman keemasan Islam, sebaliknya masa Renaisans Barat dimulai dari pertengahan abad ke-14 dengan gebrakan dari Cofernicus yang dilanjutkan - bagaikan estafet intelektual - oleh Galileo, Kepler, dan Newton, sampai akhir abad ke-16. Sejak pertengahan abad ke-16 inilah terjadi revolusi science dan technology, yang kemudian disambut dengan revolusi ekonomi. Dampak dari revolusi ekonomi, sejak pertengahan abad 18 - 20, menjadikan ekonomi Barat melesat dengan cepat membawa pendapatan perkapita Eropa jauh meninggalkan negara-negara Islam, dengan kata lain; Islam masuk ke Indonesia pada pasca keemasan, sedang Barat dalam masa menuju keemasan.

Hasil dari berbagai studi sejarah Islam di Indonesia menunjukkan bahwa pada masa awal Islam masuk ke Indonseia - dan sampai sekarang masih terasa dampaknya - adalah corak Islam yang amat kental dengan warna "fiqih sufistik" yang jauh dari sentuhan sains, sebagaimana masih terasa di berbagai pondok pesantren dan di komunitas-komunitas Islam tradisional di berbagai daerah. Lebih kurang 20 tahun lalu, pernah terjadi anggapan yang mengatakan bahwa; pintu ijtihad telah tertutup. Hal ini mendapat tantangan dari kelompok Islam reformis seperti Harun Nasution yang menyatakan bahwa pintu ijtihad tidak tertutup, hanya tidak ada yang berani masuk, mengingat serangan yang hebat dari kelompok sempit yang tradisional dan ortodoks, sampai sekarang masih saja terdengar suara sumbang bahwa sains berdampak bagi mendangkalnya agama.

Selain hal tersebut, dewasa ini banyak pendapat atau mitos yang tampaknya benar dan rasional, namun dalam realitanya keliru dan tidak menjadi kenyataan. Mitosmitos ini harus dilawan sebelum kita melangkah membangun institusi pendidikan yang kita cita-citakan.

\section{Melawan Mitos}

Kita perlu melawan bebarapa mitos dalam membangun sesuatu. Mitos boleh jadi merupakan paradigma, pendapat atau keyakinan yang kita anggap benar dan masuk akal, namun dalam realitanya keliru dan menyesatkan sehingga menggagalkan pencapaian cita-cita (core values), beberapa di antaranya adalah:

Mitos 1: $\quad$ Kita tidak dapat membangun pendidikan atau perguruan yang besar dan visioner, karena tidak memiliki dana, sarana, prasarana, dan tidak memiliki kampus perguruan, makin besar dana dan sebagainya makin mudah membangun pendidikan atau perguruan yang kita cita-citakan.

Realitanya: Banyak dana bahkan lebih dari cukup justeru menggagalkan pembangunan pendidikan atau perguruan. Banyak lembaga-lembaga pendidikan atau perguruan yang lahir dan menjadi besar, berangkat dari dana seadanya bahkan di bawah minimum. 
Mitos 2: $\quad$ Mustahil membangun pendidikan atau perguruan tanpa adanya orang yang mengerti pendidikan dan pemimpin yang berwibawa.

Realitanya: Banyak pendidikan atau perguruan yang baik dan bermutu, yang pada awalnya dilakukan oleh orang awam dalam pendidikan dan tidak memiliki pemimpin berkharisma yang tinggi.

Mitos 3: $\quad$ Upaya membangun pendidikan atau perguruan tidak mungkin dapat diwujudkan tanpa adanya dukungan atau bantuan dari penyandang dana, jaminan dari pemerintah atau kekuatan-kekuatan, atau uluran tangan dari pihak luar.

Realitanya: Banyak lembaga-lembaga pendidikan yang bergengsi, yang lahir dan berkembang dengan kekuatan internal. Dukungan atau bantuan dana dan fasilitas dari luar justru datang setelah pihak luar melihat adanya tanda-tanda kesuksesan yang diraih dan masa depan yang cerah.

Mitos 4: $\quad$ Membangun pendidikan atau perguruan memerlukan situasi dan kondisi aman, pasti dan partisipatif, bukan dalam situasi-situasi tidak menentu, apatis, dan statis, apalagi chaos.

Realitanya: Banyak lembaga-lembaga pendidikan dan perguruan yang visioner justru lahir dalam kondisi yang kurang mendukung atau bahkan chaos karena hal ini dianggap sebagai tantangan, dan sesungguhnya di dalam yang chaos itu tersimpan kekuatan-kekuatan dan peluang-peluang positif untuk membangun.

Mitos 5: $\quad$ Membangun pendidikan yang bergengsi memerlukan tenaga ahli atau konsultan yang benar-benar ahli dari negara maju yang sudah teruji reputasinya.

Realitanya: Lembaga pendidikan yang bergengsi justru lahir dari kekuatan local indigenous dan local wisdom; bantuan dan tenaga ahli justru datang ketika mereka melihat adanya tanda-tanda kesuksesan dari lembaga pendidikan yang bersangkutan. Modal, tenaga dan ahli yang datang dari luar justru melamar untuk berpartisipasi.

Mitos 6: Untuk mencapai lembaga pendidikan yang bergengsi, perlu mengalahkan atau memenangkan dari lawan yang lebih unggul.

Realitanya: Justru pembangunan lembaga pendidikan atau perguruan perlu bekerja sama dalam jaringan yang erat dan dinamis dengan lembaga-lembaga pendidikan atau perguruan lain - the web is seamless - dengan prinsip win-win bukan lose-win dalam kaidah agama-agama, "orang tidak dapat berjaya sendiri di tengah-tengah orang lemah" dan "orang justru lebih berjaya ketika berada ditengah-tengah orang yang berjaya".

Mitos 7: Dalam usaha untuk membangun, termasuk membangun pendidikan atau perguruan, kita sering terjebak dalam pilihan hitam-putih, memilih salah satu "A" atau "B".

Realitanya: Yang baik dan benar adalah kita dapat memilih keduanya "A" dan "B" atau dapat menciptakan alternatif lain sebagai sintesa dari keduanya. 
Mitos 8: Dalam membangun pendidikan atau perguruan yang besar dan visioner kita harus berakit-rakit dahulu, berenang-renang kemudian, yaitu bekerja keras lebih dahulu, memanen keuntungan belakangan.

Realitanya: Benar mitos tersebut, namun bagi pembangunan pendidikan yang benar-benar visioner keuntungan materi bukanlah tujuan utama, hal itu datang sendiri mengikuti kebesaran atau kemajuan lembaga yang dibangun. Membangun lembaga yang besar dan benar-benar visioner adalah kerja yang never finishing. Keberhasilan membangun pendidikan yang visioner selalu di-guided oleh core values, yang melampaui batas-batas beyond - mencari keuntungan (making money).

Mitos 9: $\quad$ Pembangunan pendidikan atau perguruan yang visioner tidak mungkin dapat diwujudkan tanpa adanya strategi perencanaan yang brilian atau cerdas.

Realitanya: Banyak lembaga-lembaga pendidikan yang besar dan visioner dimulai dari persiapan yang sederhana tanpa strategi perencanaan yang canggih. Strategi yang canggih dan jitu justru muncul bersamaan dengan proses kemajuan kerja. Pendidikan visioner berkembang bagaikan teori evolusi biologi Charles Darwin "siapa yang lolos dalam seleksi alam dialah yang eksis dan terus tumbuh."

Demikianlah beberapa rentetan "mitos yang keliru" yang masih dapat kita rentang panjangkan sesuai dengan pengalaman dan kebutuhan kita.

\section{Prinsip-prinsip Membangun Institusi Pendidikan yang Islam Based}

Tujuan penulisan ini adalah menghasilkan konsep pendidikan yang mampu menghasilkan clock builders, yaitu pembangun, pembaru, dan pengabdi. Clock builders adalah pembangun waktu, pembuat sejarah -positif-; Clock builders adalah orangorang yang secara inklusif mampu bekerja sama dengan pihak-pihak lain dalam budaya multikultural demi memenuhi panggilan agama dan kemanusiaan, bukan timeteller atau orang-orang yang hanya pandai berbicara dan menghafal pelajaran. Bayangkan betapa kagumnya kita, jika kita bertemu dengan seorang time-teller yang mampu menceritakan kembali sejarah zaman keemasan Islam dari abad 8 - 14, namun tidak mampu menangkap apa maknanya dan tidak mampu menawarkan konsep baru atau analisa baru bagaimana sebaiknya umat Islam menatap masa depannya. Mengapa Islam terpuruk? Bukankah ajaran Islam itu sempurna? Apa yang salah dengan Islam? dan seterusnya. Sebaliknya, seorang clock-builders adalah orang yang tidak pernah berhenti berfikir dan berbuat untuk menjawab pertanyaan-pertanyaan tersebut, ia selalu berada dalam proses membangun. Seorang time-teller dapat memberitahu anda bahwa "museum ini didirikan pada hari Rabu, 15 Juni 1405, jam 13.15 dan 10 detik". Seorang time-teller adalah hit and run yaitu hanya mementingkan kehebatan diri-sendiri, bangga jika orang lain memujinya.

Bagaimanapun konsep berikut ini masih merupakan mimpi untuk membangun teori pendidikan yang dicita-citakan, karena konsep ini akan berhadapan dengan musuh terbesar manusia sepanjang hayat, yaitu nafsu dan keserakahan manusia, seba- 
gaimana dikatakan oleh Nabi Muhammad saw. bahwa perang terbesar adalah perang melawan nafsu diri sendiri". Maukah kita membangun pendidikan karena panggilan agama (Islam)?

Jika kita ingin membangun teori yang relatif berlaku tetap dan universal, maka kita harus berangkat dari keyakinan yang kita imani kebenarannya, kemudian didukung dengan uraian akademik yang relevan dengannya. Beberapa prinsip yang di gunakan dalam kesempatan ini adalah:

Prinsip pertama: Nasib manusia tidak akan berubah dari buruk menjadi baik kecuali jika manusia itu mengubahnya. ${ }^{4}$ Hidup, berada di tangan Tuhan, yaitu Tuhan mengatur dan mengontrol makhluk-Nya melalui hukum-Nya, tetapi kehidupan berada di tangan manusia, manusia sendirilah yang memilih bentuk dan corak kehidupannya. Hukum Tuhan (sunnatullah) berjalan pasti, dan tidak pernah berubah, ${ }^{5}$ tidak ada satu makhlukpun yang mampu melampauinya. Tuhan tetap aktif dalam proses hukum-Nya.

Di mata manusia, luas hukum Tuhan tidak terbatas, manusia bebas memilih dan mengisinya, manusia hanya diberi batasan bahwa semuanya diciptakan Tuhan dengan tujuan untuk mengabdi kepadanya, ${ }^{6}$ yang sesungguhnya hal itu demi kebaikan manusia sendiri.

Prinsip kedua: Alam, mampu membantu manusia memenuhi semua kebutuhannya untuk membangun kehidupannya, namun alam tidak mampu memenuhi keserakahan manusia. Mahatma Gandhi pernah mengatakan; "sumber-sumber dunia cukup untuk memuaskan kebutuhan manusia, tetapi tidak cukup untuk memuaskan kerakusannya".

Prinsip ketiga: Ada 4 (empat) modal dasar abadi untuk menyusun konsep pendidikan dalam tulisan ini, yaitu; harapan, kemauan, kemampuan, dan keyakinan berhasil. Jika keempat modal dasar ini tidak dimiliki maka tidak mungkin tujuan membangun perguruan yang besar dan visioner dapat diwujudkan.

Prinsip keempat: Science and technology, menjadi instrumen utama menuju puncak pencapaiaan, sedang puncak pencapaian itu sendiri hanya dapat dicapai melalui agama.

Prinsip kelima: Kerja membangun pendidikan merupakan kerja yang tidak mengenal berhenti, sebagaimana dikatakan oleh T.S. Eliot yang digunakan oleh James C. Collin dan Jerry I. Porras dalam buku mereka "Built to Last; we shall not cease from exploration, the end of all our exploring, will be to arrive where we started, and know the place for the first time". ${ }^{7}$

Prinsip keenam: Prinsip keunggulan; keunggulan dimaksud di sini adalah kebiasaan sehari-hari yang sudah mentradisi dalam kehidupan, namun tidak statis, tetapi terus bergeraak maju, apapun halangan atau resiko yang dihadapi. Seperti yang dikatakan oleh Aristoteles; "kita adalah apa yang kita kerjakan berulang-ulang, karena itu keunggulan bukan suatu perbuatan yang sifatnya sesaat, setempat, dan dalam hal tertentu melainkan sebuah kebiasaan yang kita kerjakan terus menerus", 8 semuanya demi membangun lembaga. 
Prinsip ketujuh: Kerja membangun pendidikan merupakan kerja tanpa akhir. Prinsip ini digunakan perusahaan raksasa yang visioner dari Amerika Serikat, Walt Disney; above all, there was the ability to build and build and build never stopping, never looking back never finishing -the institution... in the last analysis. ${ }^{9}$

Prinsip kedelapan: Pegang teguh nilai-nilai inti - terus dorong kemajuan.

\section{"Preserve the core values-stimulate progress"}

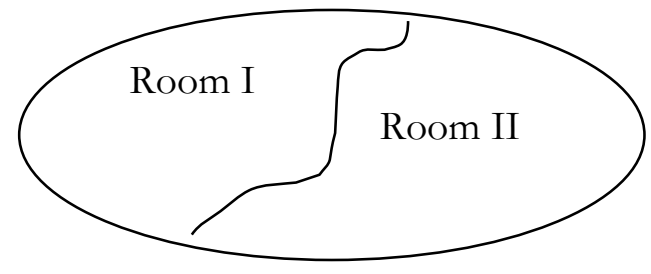

Room I: Preserve Core Values:

- Nilai-nilai instrinsik; membangun pendidikan adalah panggilan agama \& kemanusiaan.

- Ideology; membangun clock-buildes.

- Purpose; kehidupan modern \& berkeadaban.

Room II: Stimulate Progress. Sesuai dengan kondisi, orientasi, srategi, program dan sebagainya.

Room I: Nilai-nilainya relatif tetap, tidak berubah, perubahan akan terjadi sedikitnya sesudah 100 - 150 tahun.

Room II: Nilai-nilainya relatif gampang berubah, boleh jadi setiap 1 tahun, 3 tahun, 5 tahun, dan seterusnya sesuai dengan tahapan kemajuan dalam kebutuhan serta tantangan yang dihadapi.

"Kredonya" adalah sambut perubahan, tetapi jangan tenggelam dalam perubahan, capai target jangka pendek, namun bukan merupakan tujuan akhir. Capai good education, namun jangan berhenti pada good saja, teruskan ke great yang never finishing menuju built to last, kebesaran lembaga dalam keabadian.

Prinsip kesembilan: Besarkan institusinya, bukan pemimpinnya, dan bukan pula membesarkan alumninya. Kenyataannya, banyak upaya pembangunan perguruan yang keliru, yaitu yang memperoleh nama hebat dan terkenal adalah pimpinannya, bukan lembaga pendidikannya itu sendiri, yang hebat adalah alumni-alumni yang dihasilkan, bukan konstribusinya yang semakin menghebat untuk membesarkan lembaga pendidikannya atau almamaternya, dalam perspektif memenuhi panggilan kemanusiaan dan keagamaan.

\section{Langkah-langkah Membangun Lembaga Pendidikan}

Langkah-langkah membangun pendidikan yang visioner dalam era multikultural berikut merupakan turunan atau aplikasi dari "prinsip-prinsip" dan "melawan mitos" di atas. Dikembangkan dari teori Good to Great tahun 2000 dari Jim C. Clollins dan Built to Last oleh James C. Collins dan Jerry I. Porras, kemudian diperkaya dari laporan Horward R. Turnur seorang penulis TV, film dokumenter dan pendidikan da- 
lam menggelar pameran The Heritage of Islam di lima museum utama Amerika Serikat, selama tahun 1982-1983.

Langkah 1: Siapa...

Pendidikan atau perguruan yang visioner dan bermutu bagaikan "kereta api" atau "pesawat terbang" yang sudah jelas tujuannya, waktu pemberangkatan dan tempat-tempat pemberhentian sementara, bukan "taksi" yang dapat dibawa ke mana-mana sesuai dengan permintaan penumpangnya, juga bukan "angkot" yang berhenti setiap saat dan tempat sesuai dengan ada tidaknya penumpang.

Analog dengan itu, langkah pertama adalah mendapatkan "penumpang yang benar" yaitu, pemimpin, tenaga-tenaga kerja, pelayan administrasi, birokrasi, pengajar dan siswa yang tepat dan benar, serta tempatkan mereka pada tempat duduk yang benar, pada posisi dan fungsi yang tepat pula, serta keluarkan penumpang yang tidak benar. Tidak semua penumpang cocok dan membutuhkan pesawat udara, taksi, angkot, atau kapal laut, dan seterusnya. Hanya penumpang yang benar-benar memiliki komitmen, ideologi dan purpose yang benar-benar cocok dengan core values yang dapat naik dan patut mendapat tempat. Dengan kata lain, hanya mereka yang memiliki "panggilan agama", "panggilan tugas", dan "panggilan kemanusiaan", yang patut ikut serta berpartisipasi membangun pendidikan yang visioner. Pada awalnya, boleh jadi banyak orang yang hanya ikut-ikutan, tanpa menyadari pentingnya ikut serta untuk membangun pendidikan dimaksud. Jika bangunan pendidikan menunjukan prestasi dan keberdayaan serta reputasi yang baik, maka hampir dapat dipastikan bahwa pendidikan atau perguruan ini akan menjadi dambaan semua orang yang merupakan konsekuensi logis dari panggilan kemanusiaan. Semua orang yang terlibat langsung dalam perguruan ini selalu bertanya "apa yang terbaik yang dapat saya berikan pada perguruan ini".?

Langkah 2 : Hadapi...

Hadapi fakta, persoalan dan tantangan atau kesulitan, betapapun sulit dan berbahayanya - pantang menyerah - hanya "penumpang" yang benar-benar memiliki komitmen dan integritas, yang akan mampu menghadapi the most brutal facts. Para pekerja dan sivitas akademika lebih banyak dibimbing untuk menjawab pertanyaan"apa yang terbaik yang harus dilakukan dan bagaimana melakukannya demi kebaikan dan kebesaran lembaga tempat mereka bekerja", daripada memikirkan jawaban keuntungan apa yang akan diperolehnya dari lembaga tempat mereka bekerja.

Langkah 3 : Gunakan konsep Hedgehog

Konsep ini berasal dari dongeng Yunanai kuno. Berkaitan dengan ini, Isaiah Berlin membagi dunia menjadi dua, yaitu; dunia "Hedgehog " dan dunia "Foxs".

Dunia Foxs, musang tahu banyak hal kecil-kecil, sebaliknyan Hedgehog hanya tahu satu hal yang besar. Foxs adalah makhluk yang cerdas, lincah namun licik dai menghindar dari terkaman ular dengan gerakan yang manis dan lincah, sebaliknya Hedgehog adalah makhluk yang besar, berbulu kasar, kaku dan tidak rapi, ia adalah landak yang selalu bergoyang-goyang sepanjang waktu, melalui hari-harinya mencari makan dengan sederhana dan selalu peduli dengan rumahnya. 
Seiring dengan analog di atas, konsep kerja gaya Foxs adalah menyerang tujuan-tujuan kecil dan jangka pendek, mementingkan keuntungan setiap saat, menggunakan semua cara yang menguntungkan. Pertanyaannya adalah; "apa yang akan dan pasti saya peroleh", bukan "apa yang terbaik dan terbesar yang dapat saya berikan kepada lembaga tempat saya bekerja". Terakhir ini adalah pertanyaan yang menjadi obsesi Hedgehog, yang selalu peduli pada rumahnya. Konsep Hedgehog bersinergi dari 3 kekuatan: (1) Apa yang terbaik yang dapat dilakukan dalam kehidupan ini. Kecerdasannya melampaui potensinya untuk berbuat, namun memiliki dan menguasai kecakapan tidak berarti menjadi yang terbaik dalam kehidupan ini. (2) Hal apa atau faktor apa yang paling dominan atau paling kuat menggerakkan dan mengembangkan institusi pendidikan atau perguruan agar maju kedepan. Apakah jiwa wiraswasta atau enterprenenship di kalangan rekan-rekan sekerja?, atau kepercayaan yang telah diberikan oleh stake holders? atau amanah orang tua siswa?, dan seterusnya. (3) Setelah ditemukan faktor yang mempu menyalakan api atau mengobarkan semangat kerja, maka sumber energi yang ketiga adalah berfokus pada aktivitas, terus mengobarkan semanagat yang membakar faktor dominan tersebut.

Konsep Hedgehog tidak bertujuan mencapai hasil atau target pencapaian yang terbaik, strategi kerja yang terbaik, perencanaan yang terbaik, akan tetapi mengerti apa yang terbaik yang dapat mengantarkan anda menuju kebesaran institusi.

Konsep Hedgehog menuntut disiplin kerja yang tinggi, konsisten, dan komitmen yang mendalam. Bila kita telah berhasil menghasilkan dana yang banyak, sarana yang bagus, yang dapat mengangkat harkat dan martabat institusi yang tinggi, dan seterusnya, hal itu tidak berarti kita adalah yang terbaik. Fokus kerja konsep Hedgehog adalah kerja penuh semangat, melakukan yang terbaik dan terus menerus tanpa berhenti demi kebesaran institusi.

Konsep Hedgehog bertemu pada 3 lingkaran kekuatan - lihat daerah gelap:

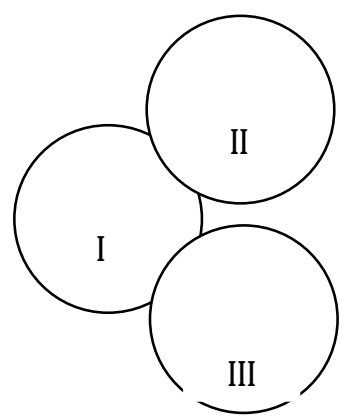
I. What you are deeply passionate about?
II. What you can be the best in the world at?
III. What drives your university engine?

\section{Langkah 4: Membudayakan dan Meningkatkan Budaya Kerjasama dengan Disiplin dan Kebersamaan yang Mantap.}

Konsep Hedgehog memerlukan disiplin dan kebersamaan kerja dengan penuh tanggung jawab, kebanggaan adalah milik bersama namun hal ini hanya merupakan salah satu titik yang perlu dilalui, bukan tujuan akhir, fokusnya adalah terus bekerja maju.

- Dengan disiplin kerja yang tinggi, kita tidak membutuhkan hierarchy; siapa yang memerintah dan siapa yang diperintah. 
- Dengan budaya kerja, disiplin tinggi dan pemikiran yang disiplin, kita tidak membutuhkan bureaucracy yang rumit.

- Dengan aksi kerja yang disiplin tidak diperlukan pengawasan yang berlebihan.

- Dengan kebersamaan, berarti beban kerja menjadi ringan.

Langkah 5: Meningkatkan teknologi kerja terus menerus, sebagai suatu sistem kerja sesuai dengan kemajuan, kebesaran, dan tantangan yang menghadang. Makin besar institusi, makin besar pula tantangan yang dihadapi, namun makin besar pula kemampuan untuk menyelesaikannya.

\section{Penutup}

Mengakhiri pembahasan ini, ada 5 butir yang ingin disampaikan sebagai penutup, yakni:

1. Bekerja pada masa kini dan masa depan dalam membangun pendidikan dan perguruan, berada dalam "bersaing dalam mutu dan waktu", serta menyingkirkan semua hambatan.

2. Sistem saingan tersebut akan didominasi oleh sistem meritocritic academic structure, yaitu sistem yang menggunakan ukuran-ukuran akademik; jujur, terbuka dan professional, siapa yang berprestasi, berjasa dan memiliki reputasi, dialah yang mendapat penghargaan dan berhak maju ke depan.

3. Sains dan teknologi merupakan faktor utama untuk memenangkan kompetisi dimaksud dan untuk memduduki tempat tinggi dalam kehidupan.

4. Belajar dari sejarah abad keemasan Islam, abad 8 - 14 ternyata Islam hebat karena menguasai sains dan teknologi. Sejak awal, muslim berkonsentrasi pada pencarian ilmu untuk membangun kehidupan duniawi yang lebih baik - bermaslahat - secara islami, jasa orang dalam kehidupan duniawi diukur dari keahlian yang dimiliki, bukan dari agama apa yang diikuti, seharusnya yang terbaik adalah muslim karena Islam adalah agama bungsu yang ajarannya sempurna.

5. Dalam zaman abad keemasan Islam tersebut orang-orang Kristen, Yahudi, dan Muslim membentuk kelompok multietnik, dan multinasional yang pertama di dunia, yang sekarang dikenal dengan sebutan "masyarakat multikultural".

\section{CATATAN AKHIR:}

1. Horward R. Turner, Sains Islam yang Mengagumkan; Sebuah Catatan Terhadap Abad Pertengahan, Terj. Oleh Zulfahmi Andri, Bandung: IKAPI, 2004.

2. Ada 18 perusahaan raksasa yang menjadi objek penelitian mereka, yang mereka sebut $\mathrm{Vi-}$ sionary Compaines, antara lain: Baeing, Ford, Sony, General Electric, Walt Disney, Motorola, dan sebagainya.

3. Horward R. Tunner, op. cit., h. 46

4. Sesungguhnya Allah tidak mengubah keadaan sesuatu kaum sehingga mereka mengubah keadaan yang ada pada diri mereka sendiri. (QS. al-Ra'd [13]: 11).

5. Sebagai suatu sunnatullah yang telah berlaku sejak dahulu, kamu sekali-kali tiada akan menemukan perubahan bagi sunnatullah itu. (QS. al-Fath [48]: 23).

6. Dan Aku tidak menciptakan jin dan manusia melainkan supaya mereka menyembah-Ku. (QS. alZariyat [51]: 56). 
7. James C. Clollins and Jerry I. Porres, Built to Last, Successful Habits of Visionary Companies, USA., Random House, 2000, h. 219.

8. Stephen R. Covey, 7 Kebiasaan Manusia yang Sangat Efektif, Alih Bahasa oleh Budijanto, Jakarta: PT. Gramedia, 1994. h. 35.

9. James C. Clollins and Jerry I. Porres, op.cit., h. 22.

\section{DAFTAR PUSTAKA:}

Ary Muchtar, Pendidikan "Studi Abad Keemasan Islam" E-Book; Sarana, prasarana dan kata baru, Dokumen Pribadi, 2005.

Horward R Turner, Sains Islam yang mengagumkan; sebuah catatan terhadap abad pertengahan, Bandung: Nuansa, 1997.

Jim Collins, Good to Great, USA.: Library of Congress, 2001.

Judith Friedman Hausen, Sociocultural Perspective of Human Learning an Introduction to Educational Antropologhy, USA.: Printice-Hall New Jersey-, 1979.

Mastuhu, Dinamika Sistem Pendidikan Pesantren, Jakarta: INIS, 1994.

Steven Weinberg, Dreams of a Final Theory, the scientists search for the ultimate Laws of Nature, New York: Random House Inc., 1993. 